\title{
A practical study for incident solar radiation intensity in Basrah province and air temperature
}

\author{
Asaad R. S. Al-Hilphy*, Aseel Hassan**, G. H. Majeed*, G. Y. Yaqoob*** \\ *Food Science Dept., Agriculture college, Basrah University, Iraq. \\ ** Material Engineering Research Institute, Shefield Hallam University, UK. \\ ***Mechanical Engineering Dept., Engineering college, Basrah University, Iraq.
}

\begin{abstract}
The study was conducted in Basrah province, Iraq in 2004 to investigation of incident solar radiation intensity there. The results showed that the solar radiation intensity increased with the increase of daylight hours and reached to maximum value at mid-day then dropped until it reached less value at four o'clock in the evening for all the different days of the year months. A maximum air temperature reached to $20,24,35,38,38,42,44$, $46,46,40,35$, and $20^{\circ} \mathrm{C}$ from Jan. to Dec. respectively.
\end{abstract}

Keywords: - solar radiation, air temperature, day hours

\section{INTRODUCTION}

A know ledge of the local solar-radiation is essential for the proper design of building energy systems, solar energy systems and a good evaluation of thermal environment within buildings [1, 2, 3, 4, 5 and 6]. In the design and study of solar energy, information on solar radiation and it is components at a give location is very essential. Solar radiation data are required by solar engineers, architects, agriculturist sand hydrologists for many applications such as solar heating, cooking, drying and interior illumination of buildings [7]. Predicted to be the clean energy of tomorrow, solar energy has been in the forefront of energy development in many developed countries and a potential source of energy to developing countries like Malaysia[8].

Al-Hilphy [9] stated that the intensity of solar radiation increased significantly $(\mathrm{p}<0.05)$ as daylight hours increasing reaching a maximum value of $740{ }^{\circ} \mathrm{W} / \mathrm{m}^{2}$ at midday and then decreased after that. Over the years, numerous models for evaluating the hourly solar radiation appeared in the literature. The first attempt to analyze the hourly global radiation data was made by Whiller [10] and Hottel and Whiller [11] on the basis of solar radiation data of various locations in U.S.A., to obtain the variation of hourly to daily radiation ratio against sunset hour angle [12]. A know ledge of the local solar-radiation is essential for the proper design of building energy systems, solar energy systems and a good evaluation of thermal environment within buildings [13-18].Madhi [19] Found in the city of Basrah, the measured and calculated solar radiation intensity that incident on the inclined surface $20 \mathrm{deg}$. angle in September 1984 was increased with the increase in daylight hours and up to the maximum value at midday and then down to the end of the day, when daylight hours 9,10 , 12,14 and 16 , the values of the measured solar radiation intensity were $965,1070,945$, and $500 \mathrm{~W} / \mathrm{m}^{2}$ also, the calculated were 770, 910, 990, 850 and $450 \mathrm{~W} / \mathrm{m}^{2}$ respectively.The aims of present study to investigation the air temperature and incident practical solar radiation intensity on the Basrah province and study their changes during different times.

\section{MATERIALS AND METHODS}

Solar radiation intensity was measured by pyranometer device which manufactured by Kipp and Zonen Company, Netherlands, type CM11.A factorial experiment with completely randomized design was used. LSD test at 0.05 significantly level was used to compare among treatments means using SPSS software [20]. The monthly average of solar radiation intensity was taken to three different days of each month. Air temperature was measured using thermometer which made of England.

\section{RESULTS AND DISCUSSION}

\section{Solar radiation}

Observed from figures 1 to 12 which show the practical solar radiation intensity during daylight hours for different days with clear sky in the all months of the year 2004, that the solar radiation intensity increased with the increase of daylight hours and reached a maximum value at mid-day then dropped until it reached less value at four o'clock in the evening for all the different days of the year months. This is due to the Earth's rotation on it is axis and as a result change solar angles with daylight hours, which include zenith angle and altitude angle and azimuth angle and reaches the value of the last to zero at midday and to great value at sunrise and sunset as well as changing the angle at hour angle with the daylight hours. These results are agreed with [21, 
22] Who confirmed that the intensity of solar radiation increases with increasing daylight hours and up to a maximum value at midday then reduced after that.The results showed that the practical solar radiation intensity at 12:00 in June less than 11 and 13 hours at the same month, this due to present little clouds in the sky at 12:00 only.

The highest intensity of solar radiation was $1024 \mathrm{~W} / \mathrm{m}^{2}$ at 12:00 in February while the less solar radiation intensity was $823.29 \mathrm{~W} / \mathrm{m}^{2}$ at 12:00 in October.

\section{Air temperature}

The results showed in the Figs. of 1 to 12 that the air temperature has increased with the increase in daylight hours and reached a maximum value at three o'clock in the afternoon in Jan., Mar., Jun., Aug., Sep. and Dec. and at 14:00 pm in Feb., Apr., Jul. and Nov. and at 13:00 pm in Oct. then dropped. For example, air temperatures reached to $10,10,11,14,17,18,19,20,15^{\circ} \mathrm{C}$ during the day hours $8,9,10,11,12,13,14,15,16$ respectively in Jan. On the other hand, A maximum air temperature reached to 20, 24, 35, 38, 38, 42, 44, 46, 46, 40,35 , and $20^{\circ} \mathrm{C}$ from Jan. to Dec. respectively.

The reason for the increase in air temperature with increasing daylight hours is to increase the intensity of solar radiation falling on the ground. The presence of differences in the maximum value of the temperature of the atmosphere is due to the presence of dust, as well as some scattered clouds in the atmosphere, leading to influence the intensity of solar radiation which directly impact on the temperature. These results agreed with $\mathrm{Al}-$ Hilphy[23], Al-Hilphy[24], Al-Hilphy et al.[9] Al-Hilphy et al. [25], Al-Hilphy[26] and Al-Hilphy et al. [27] Who found that practical solar radiation intensity falling on horizontal surfaces and inclined surfaces with angle of 30 degrees has increased significantly $(\mathrm{P}<0.05)$ with increasing daylight hours and reached a maximum value at 12:00 noon then decreased thereafter to reach the lowest value at four o'clock pm.

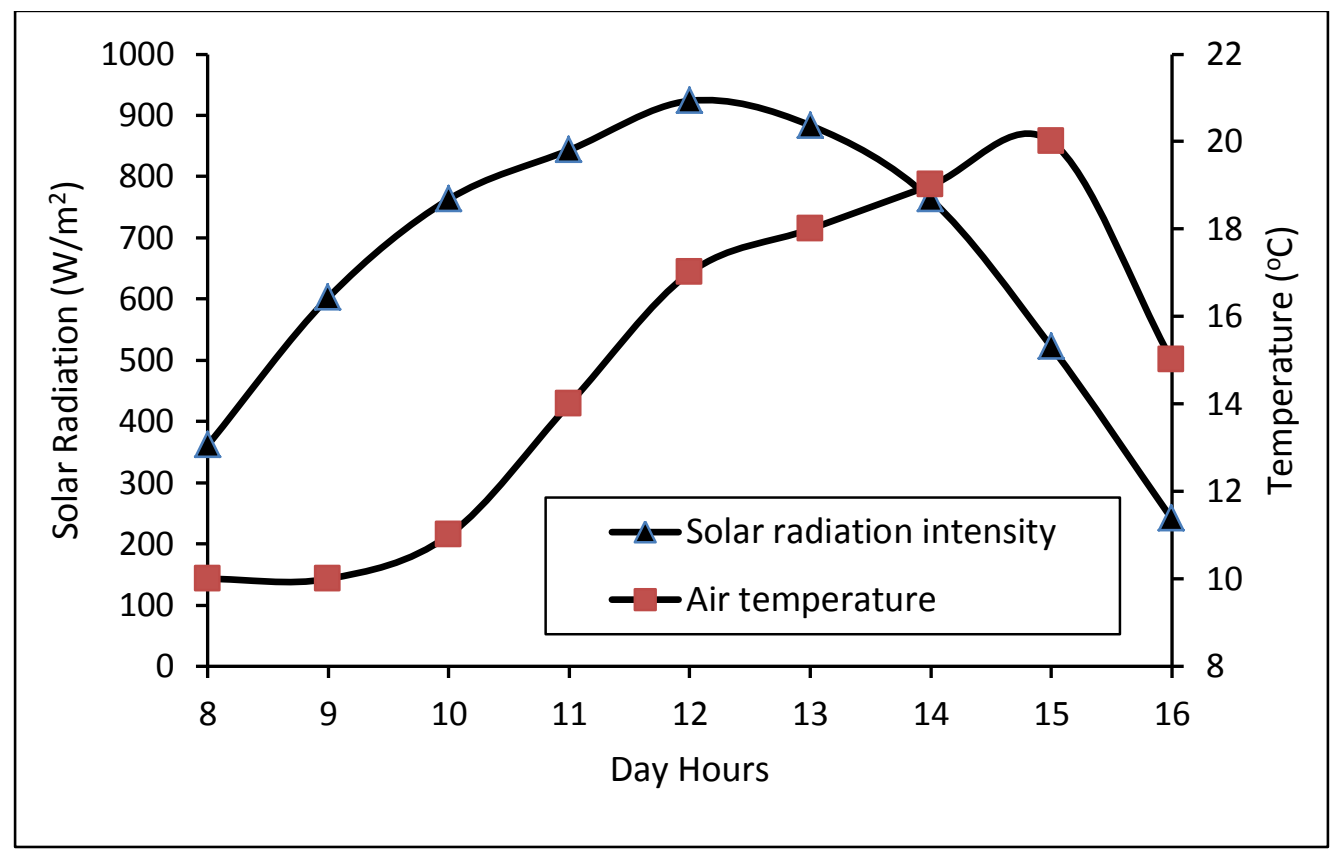

Fig.1. Incident solar radiation intensity on an inclined surface is making an angle $40^{\circ}$ with the horizontal in January. 


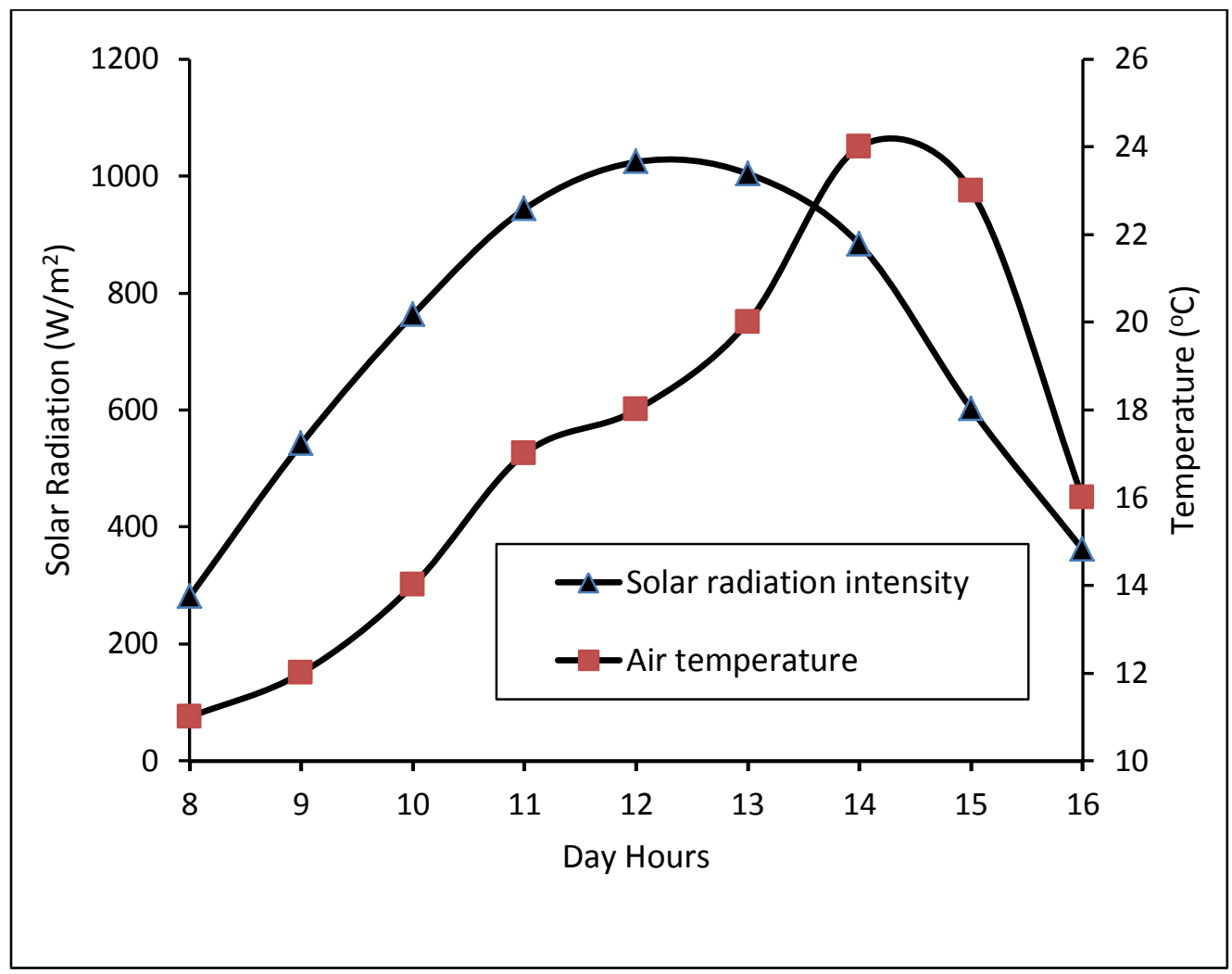

Fig.2. Incident solar radiation intensity on an inclined surface is making an angle $40^{\circ}$ with the horizontal in February.

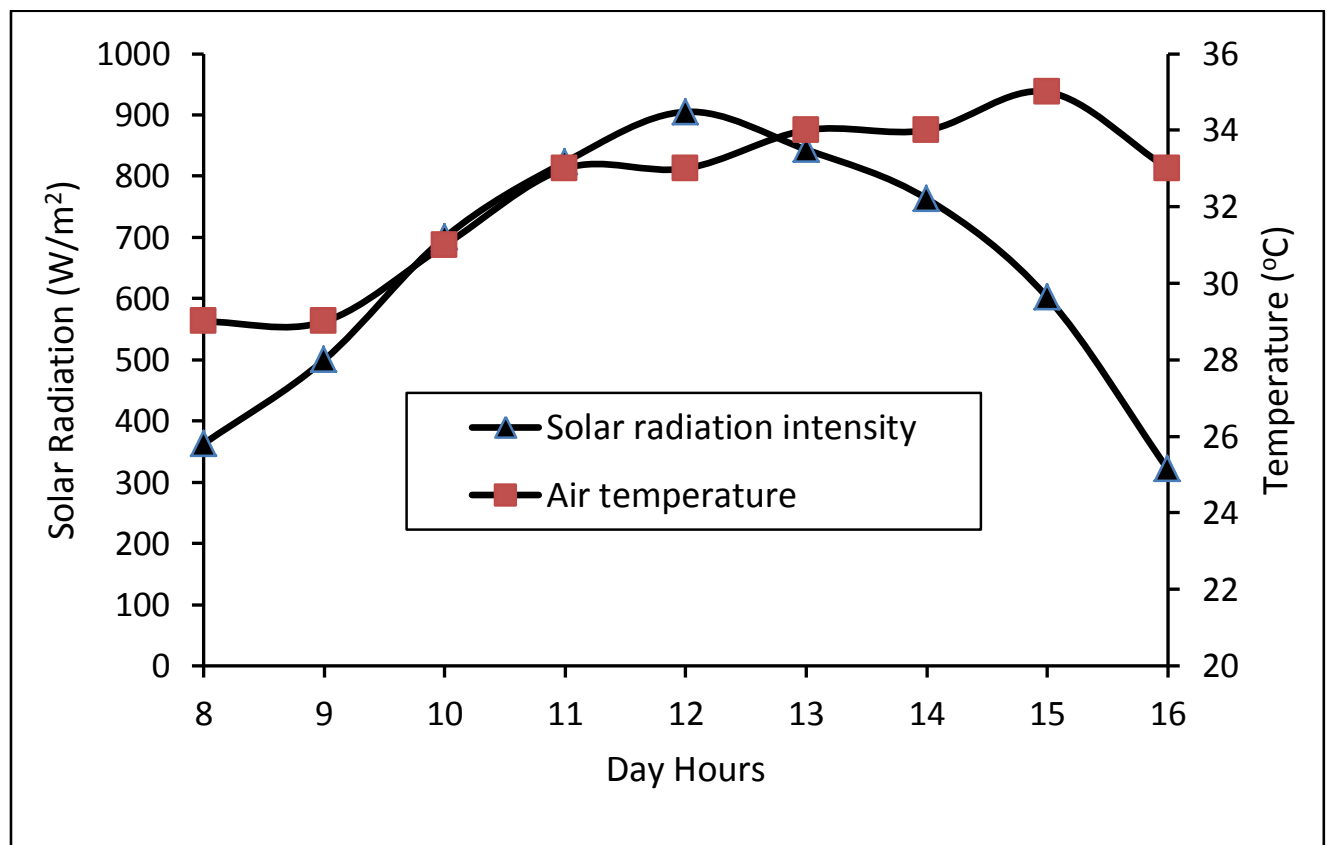

Fig.3. Incident solar radiation intensity on an inclined surface is making an angle $40^{\circ}$ with the horizontal in March. 


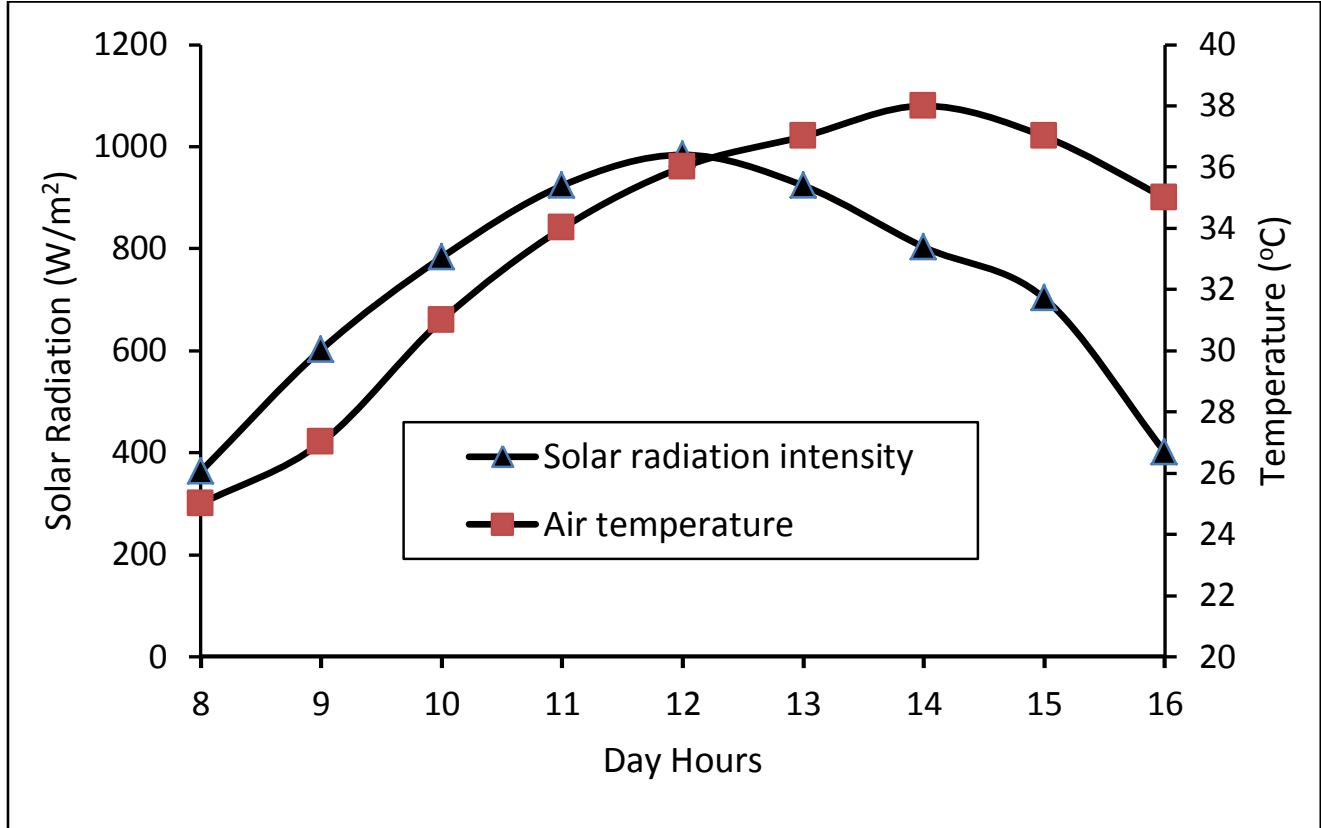

Fig.4. Incident solar radiation intensity on an inclined surface is making an angle $40^{\circ}$ with the horizontal in April.

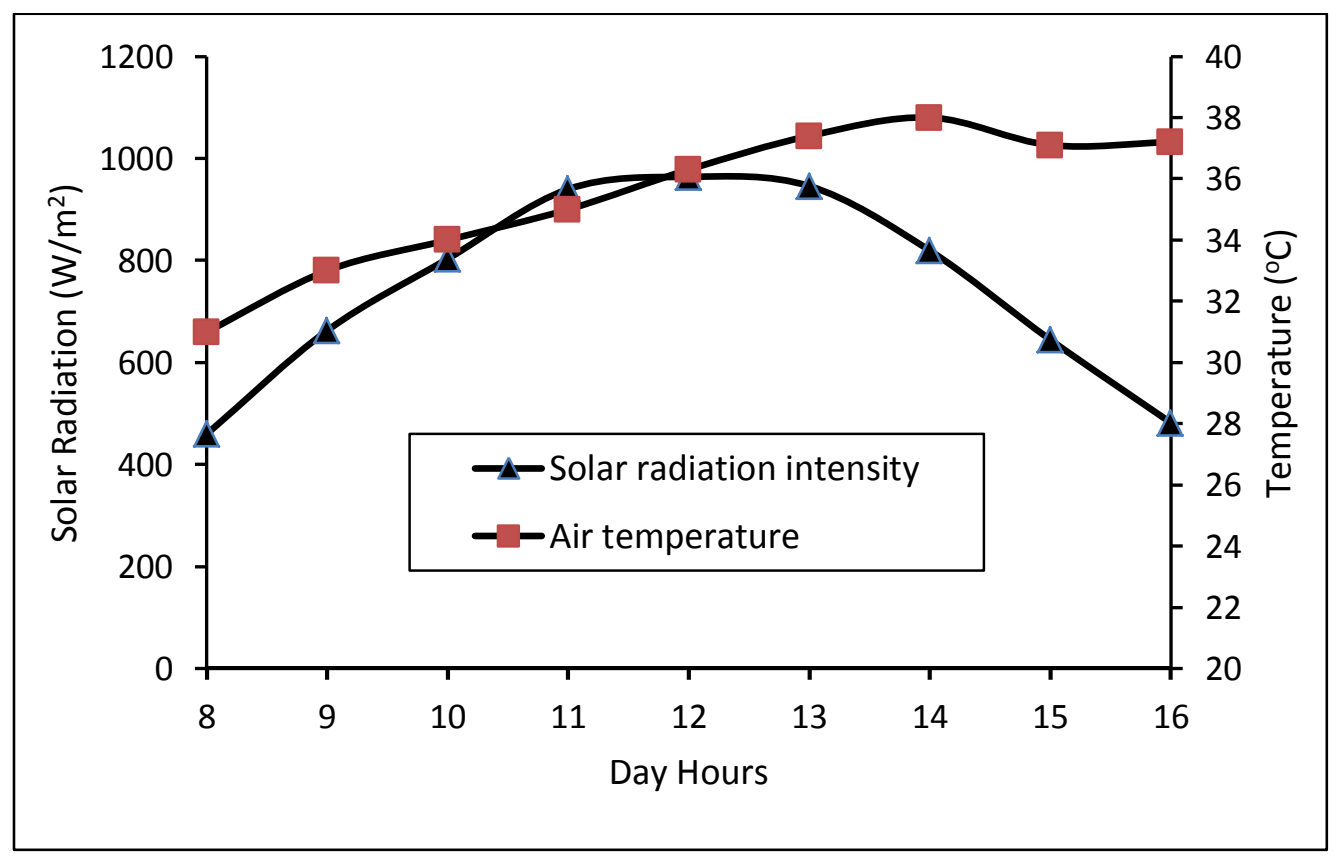

Fig.5. Incident solar radiation intensity on an inclined surface is making an angle $20^{\circ}$ with the horizontal in May. 


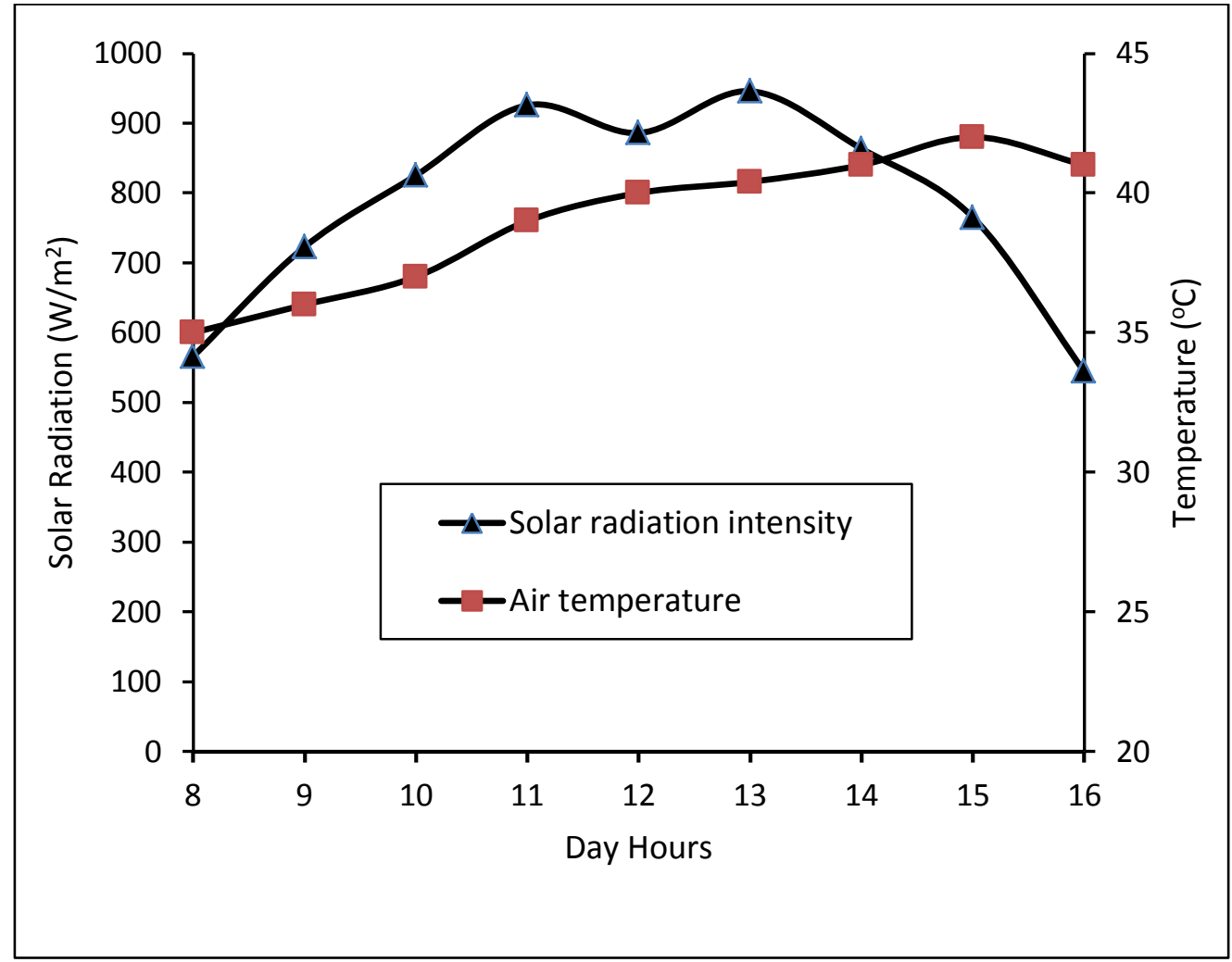

Fig.6. Incident solar radiation intensity on an inclined surface is making an angle $20^{\circ}$ with the horizontal in June.

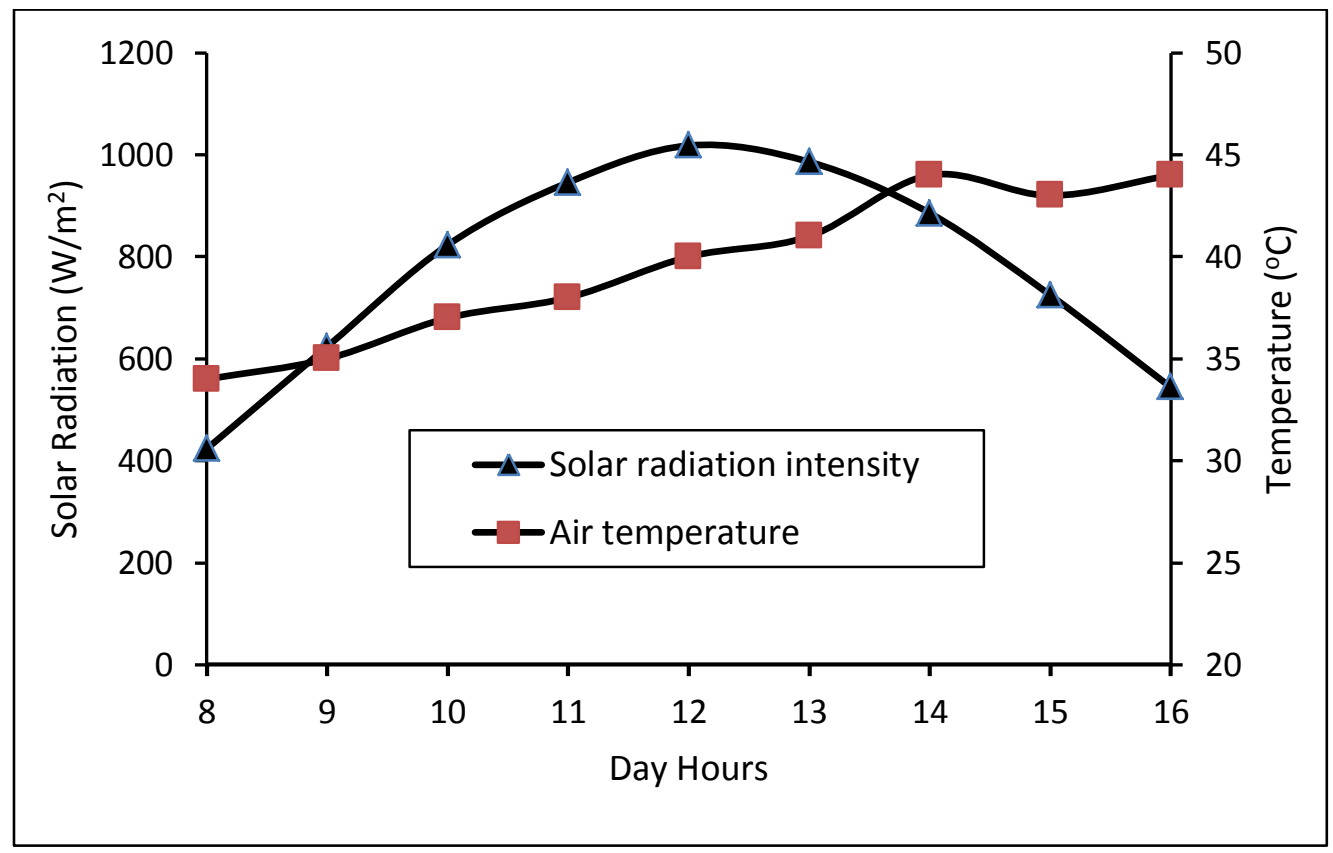

Fig.7. Incident solar radiation intensity on an inclined surface is making an angle $20^{\circ}$ with the horizontal in July. 


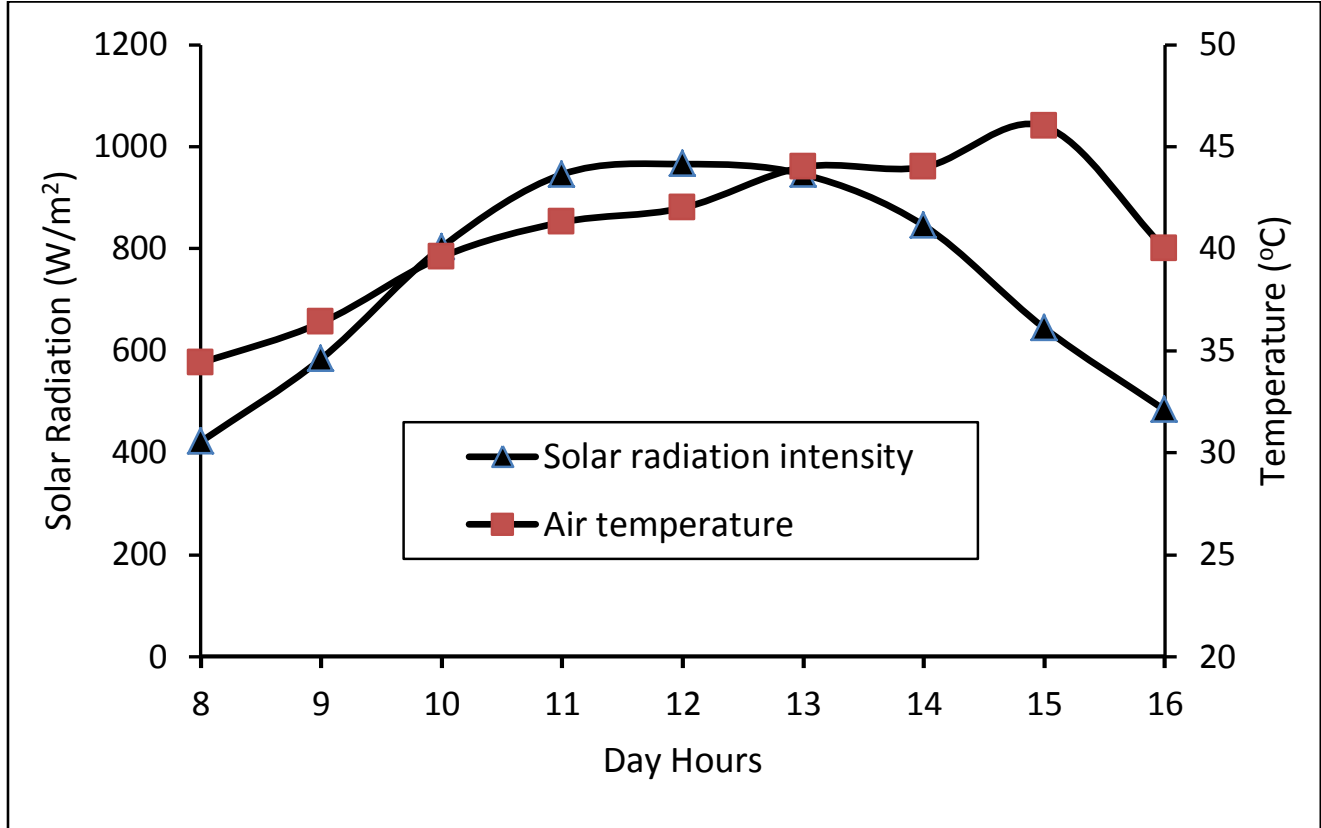

Fig.8. Incident solar radiation intensity on an inclined surface is making an angle $20^{\circ}$ with the horizontal in August.

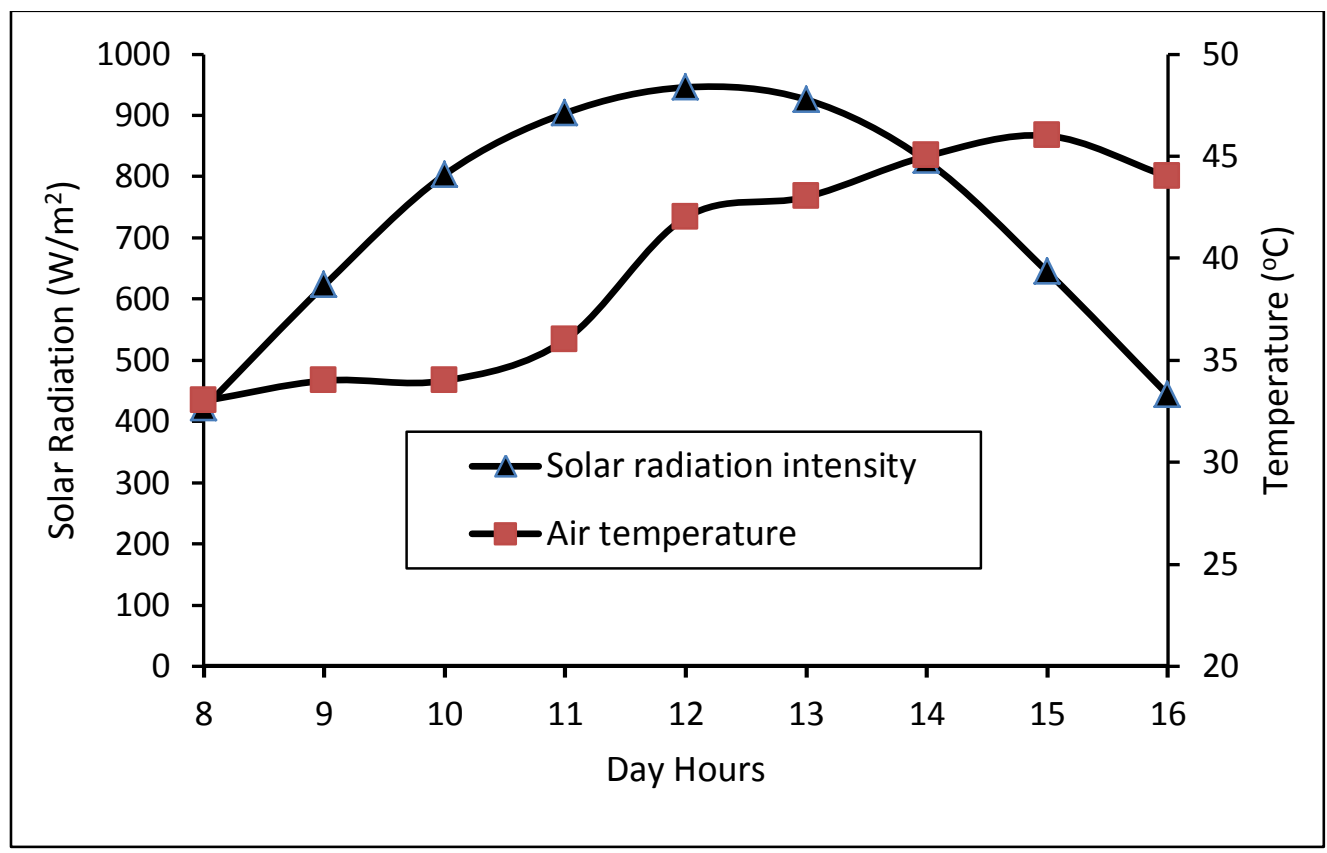

Fig.9. Incident solar radiation intensity on an inclined surface is making an angle $20^{\circ}$ with the horizontal in September. 


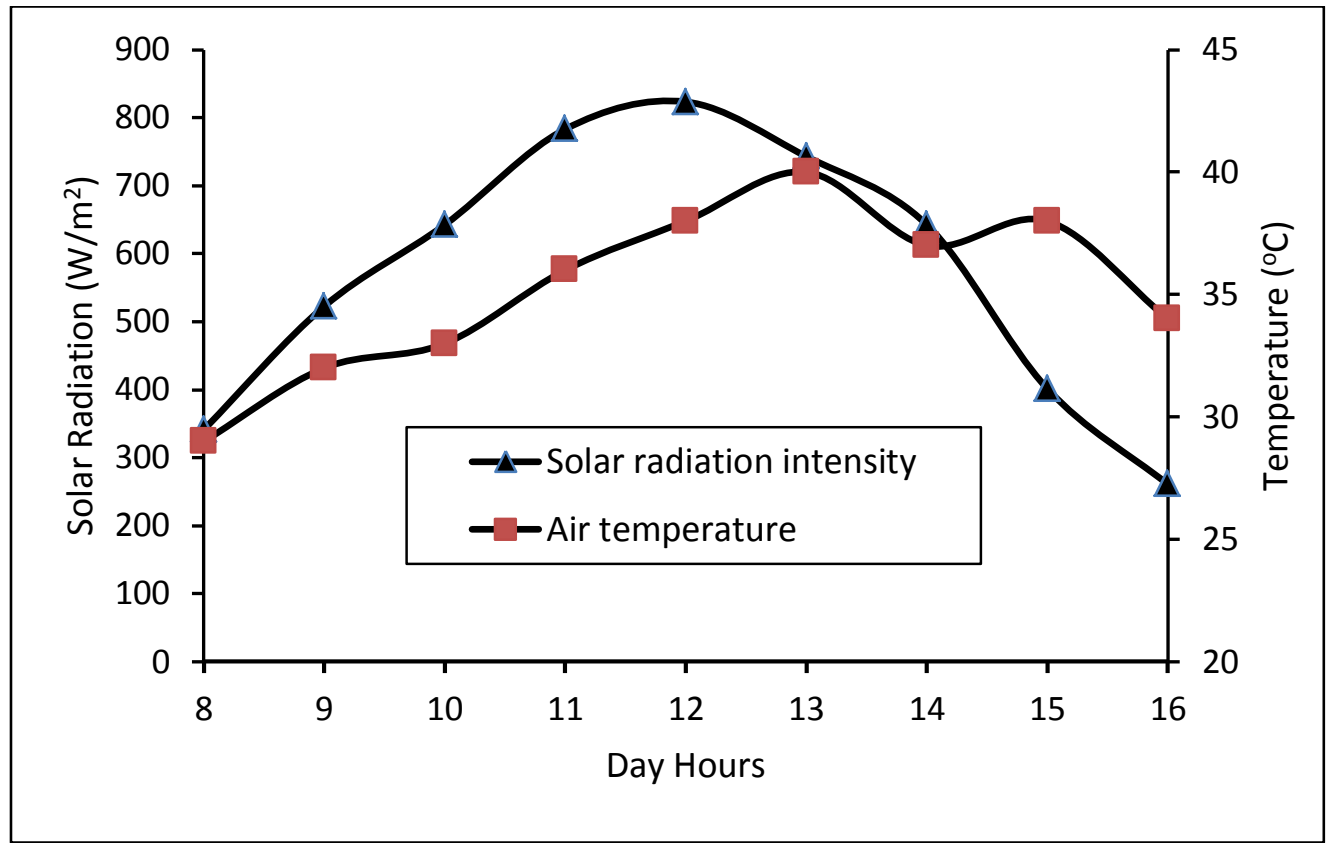

Fig.10. Incident solar radiation intensity on an inclined surface is making an angle $20^{\circ}$ with the horizontal in October.

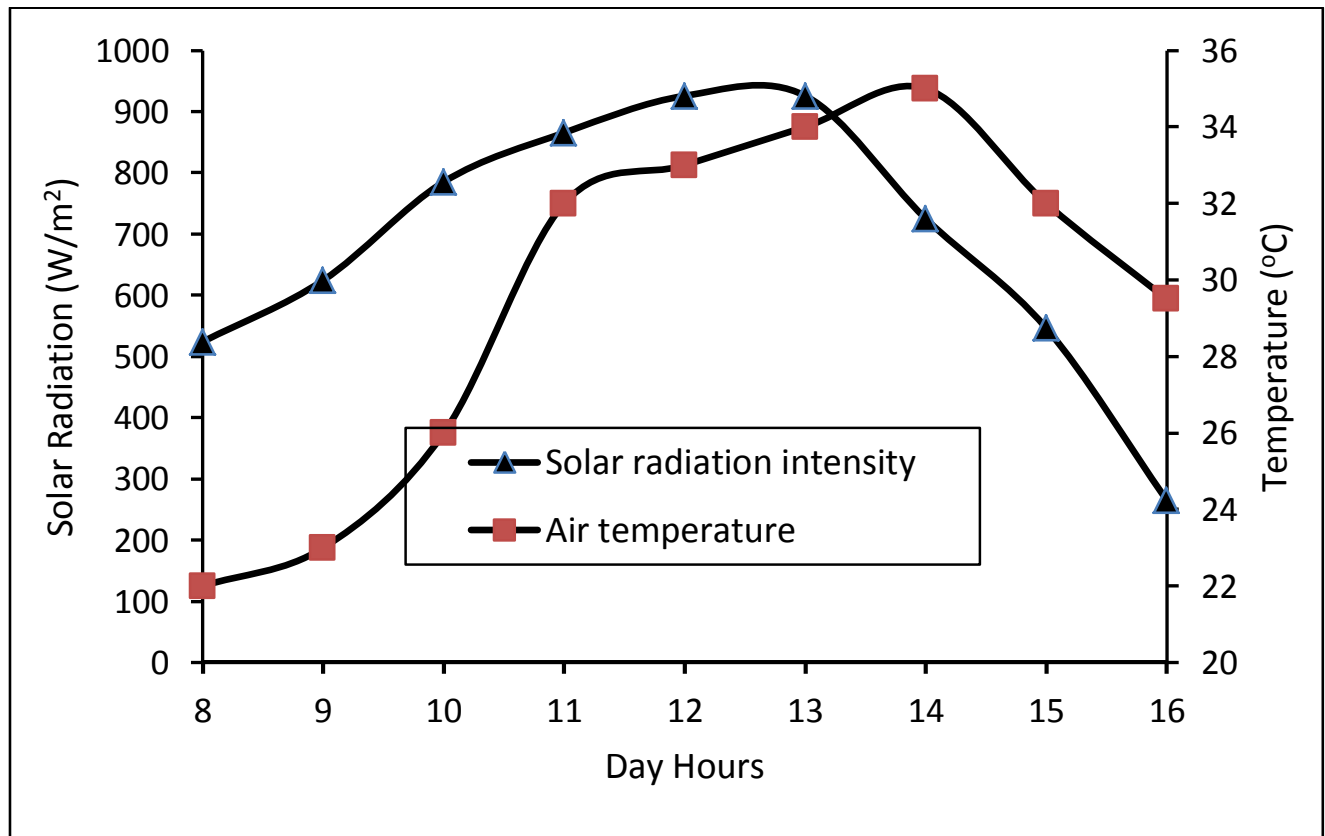

Fig.11. Incident solar radiation intensity on an inclined surface is making an angle $40^{\circ}$ with the horizontal in November. 


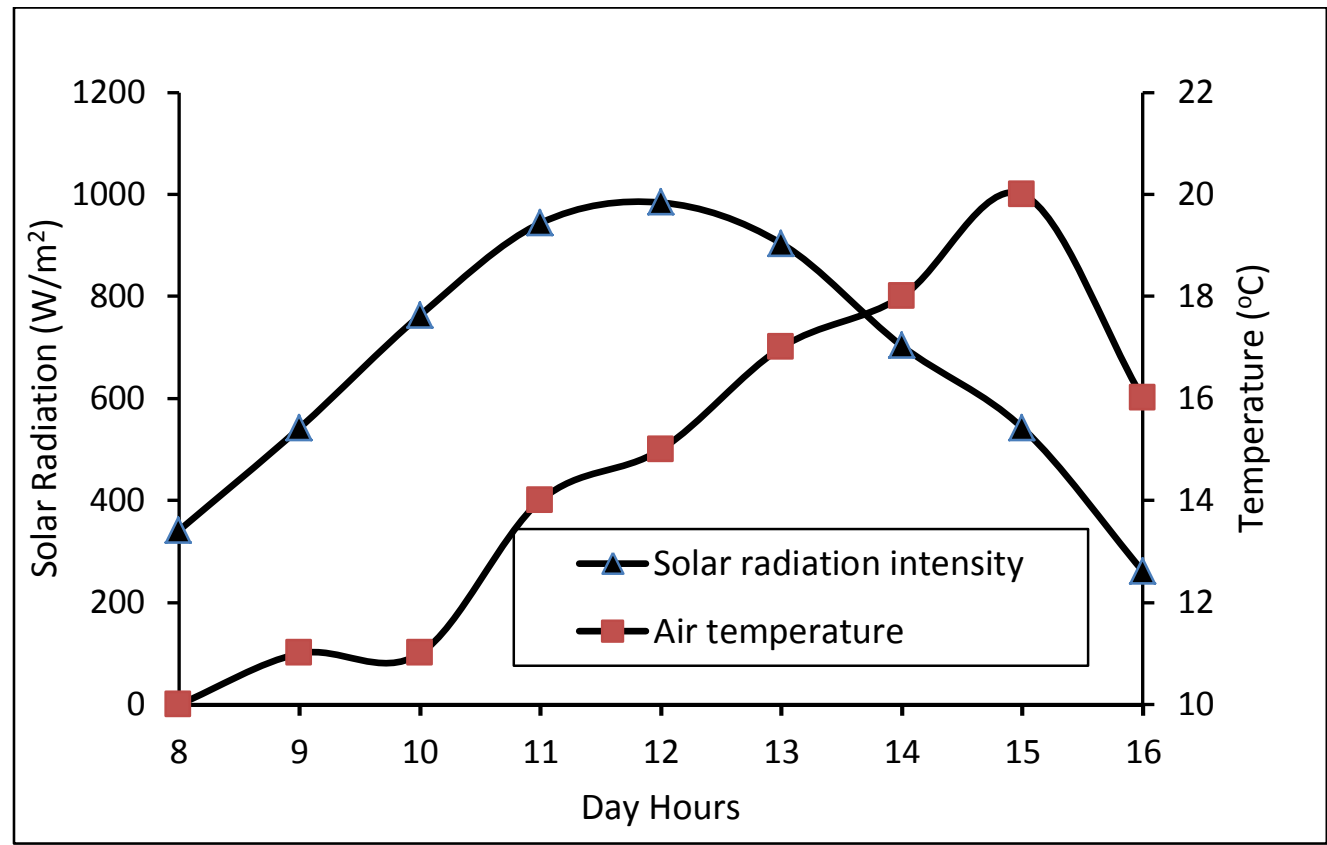

Fig.12. Incident solar radiation intensity on an inclined surface is making an angle $40^{\circ}$ with the horizontal in December.

\section{CONCLUSION}

Throughout the results of the study, solar radiation was increased with increasing day hours and reached to maximum value at mid day then reduced. Air temperature was increased with increase of day hours and reached to maximum value at three o'clock in the afternoon in Jan., Mar., Jun., Aug., Sep.and Dec. and at 14:00 pm in Feb., Apr., Jul. and Nov. and at 13:00 pm in Oct. then dropped.

\section{REFERENCES}

[1] P. J. Lunde. Solar thermal engineering. Willey, New York . (1980).

[2] Z. Lu, Piedrahita RH, Neto. CDS Generation of daily and hourly solar radiation values for modeling water quality in aquaculture ponds. Transactions of the ASAE, 41(6):1853-9. (1998).

[3] M.A. Machler, Iqbal M. A modification of the ASHRAE clear-sky irradiation model.ASHRAE ,Transactions, 91(1a):106-15. (1985).

[4] T.J. Cartwright. Here comes the Sun: solar energy from a flat-plate collector. In: Modeling the world in a spreadsheet-environmental simulation on a microcomputer. London: The Johns Hopkins University Press, p. 121-44. (1993).

[5] J. H. Trujillo. Solar performance and shadow behaviour in buildings - case study with computer modelling of a building in Loranca, Spain. Building and Environment. 33(2-3):117-30. (1998).

[6] ASHRAE. Handbook: HVAC applications. Atlanta (GA): ASHRAE. (1999).

[7] H.W. Li, J.C. Lam. Solar heat gain factors and the implications for building designs in subtropical regions. Energy and Buildingsz. 32(1):47-55. (2000).

[8] M. J. Ahmad \& G.N. Tiwari. Solar radiation models - review. International Journal of Energy and Enviromental.Vol. 1, 3, pp.513-532. (2010).

[9] A.R.S. Al-Hilphy.; A. K. Nasser and R. H. Muhson. Drying local camel sausage by solar dryer and study their chemical, microbial and organoleptic characteristics. American Journal of Food and Nutrition. 3(1): 22-30. ISSN: 2157-0167. USA. . (2013a).

[10] A. Whiller. The determination of hourly values of total solar radiation from daily summation.Archives of Meteorology Geophysics and Bioklimatology Series B, 7, 197.( 1956)

[11] H.C. Hottel., Whiller A. Evaluation of flate plate solar collector performance. Transaction of the Conference on Use of Solar Energy, the Scientific basis, Vol. II (I), Section A. University ofArizona Press: Arizona, 74.( 1958)

[12] M. J. Ahmad, Tiwari G.N. Evaluation and comparison of hourly solar radiation models.International Journal of Energy Research, 33, 538-552.( 2009) 
[13] Z. Lu, Piedrahita RH, Neto CDS. Generation of daily and hourly solar radiation values for modeling water quality in aquaculture ponds. Transactions of the ASAE; 41(6):1853-9. (1998)

[14] M. A. Machler, Iqbal M. A modification of the ASHRAE clear-sky irradiation model. ASHRAE Transactions;91(1a):106-15.( 1985)

[15] T.J. Cartwright. Here comes the Sun: solar energy from a flat-plate collector. In: Modeling the world in a spreadsheet-environmental simulation on a microcomputer. London: The Johns Hopkins University Press, p. 121-44.( 1993).

[16] J.H.S. Trujillo. Solar performance and shadow behaviour in buildings — case study with computer modelling of a building in Loranca, Spain. Building and Environment;33(2-3):117-30. (1998)

[17] ASHRAE handbook: HVAC applications. Atlanta (GA): ASHRAE, (1999).

[18] Li DHW, Lam JC. Solar heat gain factors and the implications for building designs in subtropical regions. Energy and Buildingsz ;32(1):47-55.( 2000).

[19] S.M. Madhi. Un investigation into solar assisted desiccant-evaporative air conditioning system. MSc. Thesis.Engineering college.Basrah univ. Iraq..(1985).

[20] SPSS. Spss statistical package for window ver. 17. O. Chicago :Spss, Inc. (2009).

[21] A.A. Sebaii , S. Abaul-Enein , M.R. Ramadan \& H. EL - Gohary. Experimental investigation of an indirect type natural convection solar dryer .Energy convection and management. Vol. 43 , pp. 2251-2266 (2002).

[22] S. Krauter \& F. Ochs . An All - in - one solar home system . R10 02 - world climate \& energy events, January $6-11,(2002)$.

[23] Al-Hilphy A R. S. Development of solar dryer and study it's efficiency in drying of some fruits and vegetable. PhD. Thesis, Agric, college, Basrah Univ. 171 p. (2006).

[24] A. R. S. Al-Hilphy. Drying of Corn by Solar Energy. Basrah Journal Agric. Sci. 32(1): 255-264. (2010).

[25] Al-Hilphy,; S. M. H. Al-Shatty and A. A. Gahffr. Design and manufacturing of avacuum solar dryer for fish and study its efficiency. Part 1. Journal of Basrah Researches(Sciences) .1(39): 40-59. (2013b).

[26] A. R. S. Al-Hilphy, A. R. S. A theoretical and practical study for the incident solar radiation intensity in the Basrah province (south of Iraq). IOSR Journal of Engineering, 3(9): 25-35. ISSN: 2278-8719. (2013).

[27] A. R. S. Al-Hilphy; Ibrahim A.M. and H.H.M. Al-Rubaiy. Designing and Construction of SolarMilk Pasteurizer and Studying its Efficiency. Messan Journal for Researches, 11(21): 128-146. (2012). 